IBAD Sosyal Bilimler Dergisi

IBAD Journal of Social Sciences

dergipark.org.tr/ibad

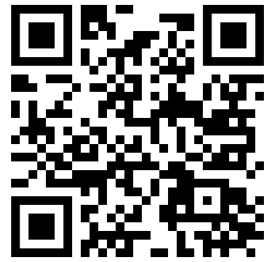

IBAD, 2021; (9): 100-116

DOI: $10.21733 / \mathrm{ibad} .829145$

Özgün Araştırma / Original Article

\title{
Vekil Dinin Uygulamadaki Görünümü: KKTC Güzelyurt Örneği
}

Appearance of Vicarious Religion in the Practice: Example of TRNC Morphou

İsmail Sezgin ${ }^{1}$

* Sorumlu yazar

${ }^{1}$ Doktora Öğrencisi, Erciyes Üniversitesi, Türkiye

PhD Student, Erciyes University, Turkey

sezgin1571@hotmail.com

ORCID ID 0000-0003-3470-7760

Makale geliş tarihi / First received : 20.11.2020

Makale kabul tarihi / Accepted $\quad$ : 24.12.2020

Bilgilendirme / Acknowledgement:

Yazar aşağı daki billgillendirmeleri yapmaktadırı
1- Bu makalede kullanılan veriler 2019 'da Necmettin Erbakan Üniversitesi'nde sunulan 'Kıbrısı Türklerin Dini

Yaşayışları Üzerine Karşılaştırmalı Bir Çalışma (Güzelyurt Örneği)' adlı yüksek lisans tezinden alınmıştır.

2- Makalemizdeki veriler 2019 yılında toplanıp yorumlanmıştır.

3- Bu makalede araştırma ve yayın etiğine uyulmuştur.

This article was checked by Turnitin. Similarity Index 27\%

Atıf bilgisi/Citation:

Sezgin, İ. (2021). Vekil dinin uygulamadaki görünümü: KKTC Güzelyurt örneği. IBAD Sosyal

Bilimler Dergisi, (9), 100-116. 
Öz

Osmanlı'dan ayrı düştükten sonra İngiliz kolonyal yönetimine geçen Kıbrıs adasında Müslüman Türkler için iki seçenek vardı: Ya bu duruma alışı İngiliz vatandaşı olacaktılar ya da anavatana göç edecektiler. Elbette her iki durumu tercih edenler de olmuştur. Hatta ilerleyen süreçte İngiliz yönetiminde bulunan diğer memleketlere bile göç yaşanmıştır. Müslüman ahaliden uzakta tecrübe edilen bu dönem Kıbrıslı Türklerin maddi ve manevi hayatında geri dönülmez değişikliklere yol açmıştır. Daha sonra bağımsız Kıbrıs Cumhuriyeti döneminde yaşanan sıkıntılar da eklenmiştir. Günümüzde ise KKTC sınırları içerisinde dini sosyal hareketlilik söz konusudur. Türkiye'nin adadaki pozisyonu bu durumu anlaşılır kılmaktadır. Ancak bu çalışmada dikkat çekilen temel husus ise birçok akademisyenin farklı teorilerle ortaya koymaya çalıştığı dini canlanmanın bireyselleştirilmiş modern tezahürleridir. 2019 Ocak ayında KKTC'nin Güzelyurt ilçesinde yapılan bir saha çalışmasında elde edilen veriler, vekil din teorisi nazarında analiz edilmeye çalışılmıştır. Vekil din isminden de anlaşılacağ pratiklerin profesyonel ellerde halk adına gerçekleşmesidir. 92 erkek, 56 kadın, toplam 148 kişiyle anket yapılmıştır. Çalışmada birçok farklı değişkene bağlı olarak veri elde edilmiştir. Ancak bu makale bağlamında değerlendirilen veriler ise Allah'a iman, ahirete iman, fatiha suresini bilme durumu, namaz kılma durumu, halk inanışları, dindarlığın göstergeleri, dini etkinliklere katılma durumu, açktan günah işleyen din adamları hakkında katılımcların görüşleridir.

\section{Anahtar kelimeler}

Din sosyolojisi, Sekülerleşme, Vekil din, Dini sosyalleşme, KKTC Güzelyurt.

\section{ABSTRACT}

There were two options for Muslim Turks on the island of Cyprus, which passed under British colonial rule after separating from the Ottoman Empire: They either got used to this situation and became British citizens or immigrated to the homeland. Of course, there were those who preferred both situations. Even that in the following process, there was even immigration to other countries under British rule. This period, experienced away from the Muslim population, led to irreversible changes in the material and spiritual life of Turkish Cypriots. Later, the problems experienced in the period of the independent Republic of Cyprus were added. Today, there is religious social mobility within the borders of the TRNC. Turkey's position on the island makes it understandable in this case. However, the main point in this study is the individualized modern manifestations of the religious revival that many academics have tried to put forward with different theories. The data obtained in a field study conducted in Güzelyurt district of TRNC in January 2019 was tried to be analyzed in terms of vicarious religion theory. As the name of vicarious religion suggests, it is the realization of religious rituals and practices in professional hands on behalf of the people. The survey was conducted with 92 men, 56 women, a total of 148 people. In the study, data were obtained depending on many different variables. However, the data evaluated in the context of this article are the opinions of the participants about belief in God, belief in the afterlife, knowing the Surah of Fatiha, prayer status, folk beliefs, indicators of religiosity, participation in religious activities and sinful clergyman.

\section{Keywords}

Sociology of religion, Secularization, Vicarious religion, Religious socialization, TRNC Morphou.

\section{GİRIŞ}


Aydınlanma dönemi sonrasında modernleşmenin bir tezahürü olarak Batı dünyasında hayatın her alanında sekülerleşme meydana gelmişti. İlerlemeye dayalı pozitivist ve evrimci bilim anlayışı ile din kamusal alandan atılarak bireyin vicdanına hapsedilmişti. Ne kadar modernleşirse o kadar seküler olunacağı düşünülmekteydi. Hatta dine son kullanım tarihi veren teorisyenler bile vardı. Bazı sosyal bilimcilere göre XXI. yüzyılda din tamamen ortadan kalkacaktı. Küresel çapta yapılan dünya savaşları ve de sonrasında yaşanan soğuk savaş dönemi insanlığı modernleşmenin niteliği ve niceliği hakkında yeniden düşünmeye sevk etti. 1960'l1 yıllardan başlayarak modernleşmenin, sekülerleşmenin ve dahi hakikatin ne olduğu tekrardan sorgulanmaya başlandı. Dünya tekrardan kutsalın dönüşüne tanıklık etmekteydi. Ancak bu durum iki yüz yıl önceki durumun aynısı değildi.

$\mathrm{Bu}$ çalışmada Grace Davie'nin kavramsallaştırdığı 'vekil din' teorisinin Kıbrıs Türk toplumundaki yansımaları verisel değerler ışığında analiz edilmeye çalışılmıştır. KKTC'nin dördüncü büyük kenti olan Güzelyurt ilçesinde 2019 Ocak ayında saha araştırması olarak yapılmış bir çalışmadan (Sezgin, 2019) elde edilen veriler kullanılmıştır. 148 katılımcının (56 kadın, 92 erkek) olduğu bu çalışmada, katılımcıların hepsi 'yerli Kıbrıslı'dır. Yerli Kıbrıslı ifadesi II. Barış Harekâtından önce adada bulunan Osmanlı'dan beri ada halkı olan Türkleri betimlemek için kullanılan bir tabirdir. Yeni kurulan Türkiye Cumhuriyeti'nden ayrı, İngiliz kolonyal dönemini tecrübe etmiş, II. Dünya Savaşı'nda Birleşik Krallık askeri olan, Hıristiyanlarla iç içe yaşamış Müslüman Türkler.

Betimlemeleri çoğaltmanın mümkün olduğu bu toplum takdir edilir ki Türkiye'de yaşayan toplumdan farklı bir Türk toplumudur. İngiliz sömürge döneminin bir asır sürdüğü adada iç savaş, ambargo, kitlesel kıyım vb. tarihi sosyal trajik hadiseler de hesaba katıldığında değişimin ve dönüşümün ne kadar hızlı olabileceği gözler önüne serilmektedir. Değişime uğrayan kurumlar arasında dinin de olacağı aşikârdır. Bu çalışma, seküler temayüller gösteren Kıbrıslı Türklerin sosyal ve kültürel açıdan ne denli dindar olduklarını ortaya koymayı amaçlamaktadır. Girizgâh olabilmesi açısından kısa bir sekülerleşme tanımı yapıldıktan sonra vekil din kavramı ele alınmıştır. Sonrasında ise elde edilen verilerde dini vekâletin niteliği ve niceliği ortaya konulmuştur.

\section{A. SEKÜLERLEŞMENIN MAHIYETI}

En genel anlamda sekülerizm, Batı'da aydınlanma çağından sonra Hıristiyan toplumunun kiliseden yaşadığı kopuşu ifade etmektedir. Rönesans ve Reform hareketleri ile başlayan aydınlanma çağının Batı toplumunu modern bir hale getirdiğini düşünen filozoflar ve sosyal teorisyenler, dinden arınmış veya kilisenin tahakkümünü bertaraf edecek bir söyleme ve eyleme muhtaçtı. Bilim insanları kilisenin tahakkümünden kurtulmak için, dini ele alırken; ilkel veya arkaik tipolojilerden modern tipolojilere doğru ilerlemeci bir söylem etrafında söz birliği yapmışçasına teoriler ortaya koydular. Bunun yanı sıra mezhepler arası çekişmelerde de kendi lehlerine tedbirler aldılar (Bayet, 2016, s. 68).

İlerlemeci pozitivizmin beslediği modern olanın seküler olması gerektiği görüşü hayatın her alanına yayılan bir düşüncedir. Bu durumdan dini kurumlar da nasibini almıştır. Bazılarına göre kilise artık insanların evlendikleri, çocuklarını yetiştirdikleri, boş zamanlar için değerlendirdikleri sosyal bir kurum haline gelmiştir (Turner, 2017, s. 280). Ancak bu ifade bile dinî kurumların tamamen terk edilmediğini göstermekte ve de ihtiyaçları gideren bir yer olarak görülmesi açısından önem arz etmektedir. Kişisel ilgilerin çeşitlendiği veya 
karmaşıklaştı̆̆ hareketlilik söz konusudur.

Dini kurumların öneminin azaldığı, toplumsal bağların çözüldüğü gerçeğine rağmen, beklenenin aksine, XXI. yüzyılda modern toplum seküler veya pozitivist bir topluma tamamıyla dönüşmemiştir. Hatta Berger geçmiş dönemde savunduğu sekülerleşme teorisi için 'gençliğimizde hepimiz aptalca işler yapmadık mı' sorusuyla mizahi bir açıklama yapmıştır (Berger, 2009, s. 247). Berger, sekülerizmin gerilediğini 'secularism in retreat' adlı makaleyi yazarak ilan etmiş ve modern dünyada önceden din kriz yaşarken şimdi de sekülerizmin kriz yaşayacağını belirtmiştir (Dereli, 2016, s. 235). Yine Berger, 1968' de New York Times gazetesinde bulunan röportajında XXI. yüzyılda dine inananların çok az olacağını hatta sekülerizme karşı koyabilmek için beraber bir arada yaşaması gerekeceğini söylemişti. Ancak milenyuma birkaç sene kala iddiasından vazgeçmiş ve sekülerleşme teorisinin yanlış olduğunu ve dinin hala daha hayatın birçok yönünde etkisinin olduğunu kabul etmiştir. Amerika'nın olabildiğince dindar olduğunu söyleyen Berger'e göre Amerika'da Chicago Üniversitesi'nin seküler eğilimli olması, İran'da Kum şehrinde dini medreseler olmasından daha ilginçtir (Köse, 2001, s. 154).

Modernleşme neticesinde dine hayatın hiçbir alanında yer vermeyen sosyal bilimciler, şimdilerde ise dini göstergeleri futbolda, rock konserinde, sanatta vb. alanlarda tekrardan keşfetmeye başlamıştır (Hervieu-Leger, 2009, s. 113). Kamusal dinin önemini yitirdiği vurgulanmakla birlikte bireysel olarak dinin yeniden şekillendiği yapılan çalışmalarla ortaya konulmaktadır. Dindarlığın yenilenen ya da göze çarpmayan boyutlarını ortaya koymak için görünmeyen din, sivil din, popüler din, halk dini, vekil din, yamalı din vb. kavramlar ileri sürülmüştür. Bu kavramlar incelendiğinde görülecektir ki hâlihazırdaki evrensel dinlerin pratikleri ya da toplumda bulunan eski kültürler, gelenekler modern simalarda yeniden teşekkül etmektedir. Örneğin Avrupa'da Hıristiyan öğretiyi benimsemediği halde kendini kültürel olarak Hristiyan görenlerin sayısı azımsanamayacak boyutlardadır. Ateistliği ile meşhur olan ve 'Niçin Hıristiyan Değilim' adlı eseri yazan İngiliz filozofu Bertrand Russell, kendisini "Protestan agnostik" olarak tanımlamıştır (Solmaz, 2011, s. 50). Buna benzer söylemleri ülkemizde 'Ateist Alevi' ya da 'Deist Müslüman' kavramlarında görebilmekteyiz. Günay, evrimci bir anlayış ile toplumun modernleştikçe dinden ve gelenekten uzaklaşacağ yönündeki beklentinin, tranzisyonel yani geçiş dönemindeki ülkelerde -Türkiye gibi- bunun tersi bir şekilde işlemekte olduğunu ifade etmektedir (Günay, 2017, s. 408). Ayrıca farklı dini sembollere bezenmiş senkretik, eklektik, ezoterik veya mistik karakterli yeni dini akımların da artarak devam etmesi, dini olana duyulan ihtiyacın giderilemediğine bir işaret olarak önümüzde durmaktadır.

Batı orjinli bir kavram olan sekülerleşmenin tanımı hakkında ortak bir uzlaşıya varılmış değildir. Sekülerleşme teorisi konusunda farklı görüşler bulunmaktadır. Bu görüşler genel olarak üç başlık altında toplanabilmektedir: Eski paradigma, yeni paradigma ve eklektik paradigma. Eski paradigmayı savunanlar klasik sekülerleşme teorisini kabul etmektedir. Yani kilise ile dini eş değer görmektedir. Bu nedenledir ki kiliseye katılımın düşük olması, onların nazarında dinin gerilemesi olarak görülmüştür. Yeni paradigmayı savunanlar ise sekülerleşmeyi Batı özelinde kabul etmektedir. Bununla birlikte bireysel olarak yaşanan dindarlığı ön plana çıkarmaktadır. Ayrıca yeni paradigma, yeni dini hareketlerin çoğalmasını modern çağda dini olana ihtiyaç olarak yorumlamaktadır. Eklektik paradigmayı savunan 
sosyologlar ise yeni paradigma savunucularının eski paradigmayı tam olarak anlamadıklarını söylemektedir. Eklektik paradigma ise sekülerleşme tezinde otorite kavramını esas alarak dinin kamusal alanda sekülerleştiğini ileri sürmektedir. Aşağıdaki başlıkta ele alınan vekil din teorisi ise yeni paradigma içerisinde yer almaktadır. Bu bağlamda pratikten ayrılsa bile iman tek başına yeterli görülmektedir. Ayrıca yeni paradigma sosyologları dünyanın yeniden doğaüstüyle etkileşimini benimsemektedir (Özay, 2020, s. 143-150).

\section{B. VEKÍL DİN TEORISII}

Grace Davie, vekil din teorisini ortaya koyan kişidir. Yine ona ait olan bir başka kavram ise 'ait olmadan inanma-believing without belonging' ifadesidir. 1994 yılında yayınladığ ${ }_{1}$ 'Religion in Britain Since 1945: Believing Without Belonging' kitabında ait olmadan inanma kavramını kurumsal dinin dışında kalan \%50'lik bir grubu betimlemek için ortaya atmıştır. Daha sonrasında bu düşüncesi onu vekil din kavramına ulaştırmıştır (Davie, 2010, s. 261). Davie ait olmadan inanma kavramını kiliseye ait olmadan Allah'ın varlığına inanma olarak yorumlamaktadır. Hatta ateistlerin bile kabul etmedikleri tanrı hakkında çok bilgi sahibi olduklarını söylemektedir (Davie, 2012, s. 3). Ona göre Avrupalı laik olduğu için değil Avrupalı olduğu için moderndir (Davie, 2012, s. 6).

'Vicarius religion' ifadesinin Türkçeleştirilmiş hali olan 'vekil din' ifadesinde, vicarius kelimesi vekil olarak çevrilse de, esasında papaz manasını ihtiva etmektedir (Davie, 2008, s. 32-33). Bu ifadeyi böyle yorumlayacak olursak din adamlarının ya da profesyonellerin halkın yapması gereken eylemleri vekâleten yaptığı manası ortaya çıkmaktadır.

Avrupa'da modernleşmenin zorunlu bir parçası kabul edilen sekülerleşme neticesinde din yok olmaya mecbur görülmüştür. Davie ise sekülerleşmenin dini tamamen ortadan kaldırmadığını düşünmektedir. Ona göre sekülerleşme ile Avrupa'nın ekonomik ve siyasi yaşamı gelişirken din kamusal alandan uzaklaştırılmıştır (Davie, 2005, s. 31-41; Davie, 2006, s. 229-237). Davie'ye göre vekil dinde temel görünüm kilise etrafında şekillenmiş bir Avrupalı dinidir. Bayramları, festivalleri, takvimleri vb. sosyal etkinlikleri Avrupa'nın tarihi kiliseleri tarafından şekillendirilmiştir (Davie, 2010, s. 262). Hristiyan geleneğindeki tüm tatiller ya da haftalar, Hristiyanlığa uygun olarak takvimde kendini hissettirmektedir. Pazar günü alışveriş yapıp yapılamayacağını Avrupa'da tartışılırken Cuma günü için böyle bir şeyin yapılmadığını söylemektedir (Davie, 2008, s. 32).

Avrupa toplumunu daha iyi anlamak adına toplumu oluşturan kitlelerin geçmişlerine ve ortak değerlerine bakmakta yarar vardır. Davie'ye göre Avrupa'nın kollektif hafızasını oluşturan temeller arasında Hristiyan-Yahudi kültürü/monoteizmi, Roma hukuk sistemi, Antik Yunan felsefesi ve de Laik Avrupa Aydınlanması vardır (Davie, 2012, s. 3). Ayrıca Avrupa'yı tek parça düşünmek de elverişsizdir. Avrupa'yı oluşturan ülkeleri: Katolik ülkeler (İspanya, İtalya, İrlanda), Protestanlığın hâkim olduğu ülkeler (Danimarka, Büyük Britanya, Kuzey İrlanda, Batı Almanya), Laik ülkeler (Fransa, Belçika, Hollanda) olarak kabaca tasnif etmek mümkündür. Davie'nin burada dikkat çektiği bir diğer husus ise Batı Avrupa'nın özellikle Protestan Kuzey ülkelerinde- sekülerden ziyade kiliseleştirilememiş toplumlar olarak kalmaya devam ettikleridir (Davie, 2005, s. 10).

Avrupa'nın kolektif hafızasını oluşturan temellerden biri de dini eğitimdir. Laikliğin koyu bir halde yaşadığ 1 Fransa'da bile Katolik dini okullara devlet yardımı esirgenmemektedir. Velilerinin talepleri siyaseten önemli bir etkiye sahiptir. Ancak Müslümanlar için aynı hoşgörü 
gösterilmemektedir. Avrupa'da özellikle Fransa'da başörtü meselesi problemli bir şekilde devam etmektedir. Müslümanlar artan terör olayları ve islamofobi nedeniyle negatif ayrımcılığa tabi tutulmaktadır. Avrupa Birliği'nin ilk 15 ülkesine baktığımızda seçmeli veya zorunlu din derslerinin var olduğunu, ilgili devletlerin tümünün dini okullara ödenek ayırdığını görmekteyiz (Davie, 2005, s. 108-112; Birekul, 2009, s. 54).

Davie, Avrupa'nın ılımlı seküler kesimlerinde bile doğum, evlenme ve en önemlisi de cenaze törenlerinde dini ritüellere insanların ihtiyaç duyduğunu söylemektedir. Vaftiz oranları geçmişe nazaran artmış; ancak bu olağan bir halde değildir. Hıristiyan inancına göre her insan günahkâr doğar ve vaftizle temizlenir. Ancak günümüzde bebekler doğar doğmaz vaftiz edilmemektedirler. İnsanlar belli bir yaşa geldiği zaman istediklerinde gidip vaftiz olmaktadırlar. Doğum esnasında yükümlülük olan ritüel değişerek belli bir yaş seviyesinde isteğe bağlı bir ritüel haline dönüşmüştür. Vaftiz oranlarının düşüşünün görünmeyen bir sosyolojik yanı daha vardır. O da doğum esnasında ölüm oranlarının ve doğurganlık oranının düşüşüdür. Vaftiz edilen bebeklerin kutsanması aynı zamanda onların erken ölmemesi için bir ümit taşımaktaydı. Ömrün uzaması, doğum oranlarının azalması ve bebek ölüm oranlarının düşmesi ile beraber insanlarda artık vaftiz talebi daha sonraki yıllarda bireysel bir tercih haline gelmektedir. Her ne kadar vaftiz olma bir tercih haline gelse de, Yunan milliyeti ve Ortodoks kilisesi arasındaki bağlılığın neticesinde vaftiz oranları ciddi bir derecede devam etmektedir. Ayrıca Kuzeyli Lutheryan Avrupa'da ve Katolikliğin yoğunlukta olduğu Güney Avrupa'da vaftiz uygulaması evrensel bir görünüme sahiptir (Davie, 2005, s. 91-92).

Davie'ye göre Kraliyet Ailesi'nde yaşanan aile geçimsizlikleri de halkın nazarında önem taşımaktadır. İnsanlar kendi ailesinde dikkat etmediği şeyleri kraliyet ailesinde veya piskoposlarda, kiliseyi temsil eden bu insanlarda görmek istemektedirler. İnsanlar inançlı olmasalar da din adamlarından inançlı olmalarını beklemektedirler. Durham piskoposu David Jenkins verdiği bir röportajda Hz. İsa'nın doğumunun mucize olduğunu söylemiş, medyada bu olay Hz. İsa'nın dirilişinin bir sihirbazlık olarak lanse edilmişti. Magazinin ve halkın diline düşen piskopos, herkes tarafından kınanmıştır. Davie'ye göre insanlar Hazreti İsa'ya inanmasalar bile papazın şüpheci olmaması gerektiğini ve Hz. İsa'nın doğumunun mucizevi olduğuna inanmasını istemektedir (Davie, 2008, s. 33).

Kraliyet ailesinin de dini bir kurum olarak işlev gördüğü Britanya'da Prenses Diana'nın cenazesi de önemli bir örnektir. Prens Charles'tan boşanıp Müslüman bir iş adamı olan Dodi el Fayed ile aşk yaşayan Diana, sevgilisiyle beraber geçirdiği trafik kazasında ölmüştü. Ölümünün üzerinden yıllar geçmesine rağmen Prenses Diana haberleri her yıl adından sıkça söz ettiren ve magazin haberlerini süsleyen bir olaydır. Burada dikkat çekilmek istenense prensten boşanan asi prensesin toplumun normlarını yıkmasına ve de Müslüman bir kişiyle sevgili hayatı yaşamasına rağmen nasıl öldüğünün ayıplanmamış olmasıdır. Cenaze töreninin ulusal kanallarda naklen yayınlanması, cenazesinde çalan şarkıların haftalarca müzik piyasasında en çok dinlenenler arasına girmesi, ölümünün popülerleşen yanıydı. Prenses Diana'nın ölümü nedeniyle birçok kişi kendi bulunduğu şehirlerdeki katedrallerde ve kiliselerde gıyabında cenaze törenlerine iştirak etmişti. Çiçeklerin bırakıldığı, mumların yakıldığı ve de hatıra defterlerine taziye mesajları yazıldığı sembolik cenaze törenleri tertip edilmişti. Bir diğer cenaze ise Fransız Cumhurbaşkanı François Mitterrand'a aitti. O ciddi manada seküler veya dinsiz kabul edilebilecek biriydi. Dindar bir gruba göre, ölürken Katolik ayinini hak etmemişti. Laik gruba göre ise cenaze töreninin Katolik usullere göre yapılması 
gereksizdi. Yine de Katolik kilisesinde tören yapılmıştı. Cenazeden bir gün önce ise alternatif olarak vefa töreni de düzenlenmişti. Yaşantılarında dindar sayılmayacak bu iki şahsiyetin cenaze törenlerinin olanca dindar özelliklere bezenmesi Davie'ye göre dinin halen toplumun kolektif hafızasında yer eden, vekil dinin önemli göstergeleri arasındadır (Davie, 2005, s. 99102).

Davie, ortaya attığı vekil din teorisinin XXI. yüzyılın ortalarına kadar yaşayacağını, ancak daha sonrasında sona ereceğini düşünmektedir. Dinin pazardaki bir meta gibi uygun bir şekilde insanların istediği zaman alıp istediği zaman bırakacağı bir pazar modeli haline geleceğine inanmaktadır (Davie, 2008, s. 42). Davie ilerleyen süreçte Avrupa'da çok dinli bir pazardan söz etmiştir. Ancak İslam hakkında ise oryantalist bir söylemi benimsemektedir. Kamusal politikalar açısından İslam'ın Avrupa'da sorunlara yol açacağını söyleyen Davie'ye göre İslam'ın Yahudi-Hristiyan geleneğinin ürünü olan Avrupa içinde barış içinde yaşaması mümkün değildir. Çünkü Müslümanlar, inançları gereği Avrupalıların benimsediği gibi seküler tutumlar sergileyemeyecektir. Buna örnek olarak da Salman Rüşdi'nin Şeytan Ayetleri etrafındaki tartışmalarını ve Fransa' da yaşanan başörtüsü tartışmalarını göstermiştir (Davie, 2005, s. 164-171).

\section{VEKIL DINNIN UYGULAMADAKİ GÖRÜNÜMÜ}

Akdeniz'in üçüncü büyük adası olan Kıbrıs jeopolitik ve stratejik öneminden dolayı tarih boyunca çok farklı medeniyetlere ev sahipliği yapmıştır. 1571 yılında Osmanlı hâkimiyetine girince ada Anadolu'dan getirilen Müslüman Türklere vatan olmuştur. 1878 yılında İngilizlere kiralandığında ise adanın mülkü Osmanlı' ya ait olmakla birlikte yönetimi İngilizlere geçmiştir. I. Dünya Savaşı'nda Osmanlı'nın İngiltere karşısında savaşa girmesi sonucunda ise 1914 yılında İngiltere tarafından tek taraflı ilhak edilmiştir. Lozan Anlaşması neticesinde ise resmi olarak İngiltere'nin kolonisi haline gelmiştir.

Ada üzerinde yaşayan en büyük dini grup Hristiyanlardır. Özelde ise Rumların tabi olduğu Ortodoks Kilisesi ilk sıradadır. Ortodoks Rumlar haricinde Hiristiyan gruplar arasında Levant asıllı Maronitler, Ermeniler, İngilizler ve Latinler yer almaktadır. Ada 1974 Barış Harekâtı ile kuzey ve güney olarak ikiye ayrılınca kuzey kısmı Türklere, güney kısmı ise Rumlara kalmıştır. Ada bölündükten sonra kuzeye yerleşen Kıbrıslı Türklerin dışında adanın kalkınması için 1974 yılından sonra Türkiye'den Kıbrıs'a iskân ettirilen Türkler vardır. KKTC sınırları içerisinde az sayıda Maronit -Maroni ya da Marûni- (Şengil, 2010, s. 3-4), Rum ve İngiliz yaşamaktadır. Ermeniler ise ada bölündükten sonra güneye geçmiştir. Günümüzde GKRY meclisinde Ermeni, Latin ve Maronit halkları adına birer azınlık temsilcisi bulunmaktadır (Dayığlu, 2014, s. 89). 1959 yılında yapılan Londra ve 1960 yılında yapılan Zurih Anlaşmaları neticesinde adanın doğusunda bulunan Dikelya üssü ile güneyinde bulunan Ağrotur üssü İngilizlerin kontrolüne bırakılmıştır. İngiliz üsleri günümüze değin varlığını sürdürmektedir.

Adanın çokuluslu ve kültürel yapısı, İngiliz sömürgesini yakın geçmişte tecrübe etmesi, batılılaşma ve modernleşme vb. faktörler göz önünde bulundurulduğunda bu küçük adada farklı dini uygulamaların olması olağan bir durumdur. Bu makale kapsamında makalenin sınırlarını zorlamasından dolayı değinilmeyen birçok faktör daha bulunmaktadır. Osmanlı Kıbrıs'ında Müslümanlar üzerinde etkili olan mistik tasavvufi hareketler, Osmanlı'dan kopuş, İngiliz yönetimine geçtikten sonra Anadolu'ya farklı zamanlarda yaşanan göç dalgaları, yeni 
kurulan Türkiye Cumhuriyeti'ndeki jakoben siyasi söylemin Kıbrıslı Türk yöneticiler tarafından benimsenmesi, bağımsız müftülük makamının İngiliz memuru pozisyonundaki fetva eminliğine dönüştürülmesi, din eğitimin sağlıklı ve eşit koşullarda yapılamaması, Türk liderliği arasında vakıfçı-cumhuriyetçi çekişmesi vb. birçok faktör Kıbrıslı Türklerin dini hafızasını ve dini pratiklerini etkilemiştir.

$\mathrm{Bu}$ çalışma kapsamında değerlendirilen veriler zamanla sekülerleşen Kıbrıslı Türklerin yeniden şekillendirdiği dini pratikler olarak görülebilir. Bu durum Levi-Strauss'un deyimiyle brikolaj etkisi yapan bir olgudur. Brikolaj mevcut bulunan şeyleri değişen şartlara göre yeniden yapılandırmaktır (Levi-Strauss, 1996, s. 43-44). Turner ise bu durumu DIY dinleri olarak yorumlamaktadır. DIY ifadesinin açılımı 'do it yourself-kendin yap'tır. DIY, yapı marketten demonte olarak alınan bir eşyayı kişinin belli bir plan üzerine kurmasıdır. Dini uygulamada ise birey elinde bulunan şeyleri yeniden kendi şartlarına göre yapmaktadır. Elindeki nesneler aynı dini öğeler olabileceği gibi farklı kültürlere de ait olabilmektedir (Turner, 2012, s. 217). İster brikolaj denilsin isterse DIY dinleri, sonuçta elde edilen malzeme ezoterik, senkretik, eklektik ya da yamalı bohça gibi duracaktır.

2019 Ocak ayında Güzelyurt ilçesinde yapılan çalışmaya 156 kişi katılmış olup anketin geçerlilik şartlarından geçen 148 kişinin anketi çalışma kapsamında değerlendirilmiştir. Erkek katılımcı sayısı 92, kadın katılımcı sayısı 56'dır. Çalışmada birçok veri elde edilmiştir. Bu makale bağlamında değerlendirilen veriler ise Allah'a iman, ahirete iman, Fatiha suresini bilme durumu, namaz kılma durumu, halk inanışları, dindarlığın göstergeleri, dini etkinliklere katılma durumu, açıktan günah işleyen din adamları hakkında katılımcıların görüşleridir.

Tablo 1. Iman esasları

\begin{tabular}{ccc} 
& $\begin{array}{c}\text { Allah'ın } \\
\text { varlığına iman }\end{array}$ & $\begin{array}{c}\text { Ahiretin varlığına ve öldükten sonra } \\
\text { dirilmenin hak olduğuna iman }\end{array}$ \\
\hline $\begin{array}{c}\text { Kesinlikle } \\
\text { inanıyorum }\end{array}$ & $\% 84,5$ & $\% 51,4$ \\
\hline
\end{tabular}

Kısaca iman esaslarl; Allah'a, meleklerine, kitaplarına, peygamberlerine, ahiret gününe, kadere, öldükten sonra dirilmenin hak olduğuna, hayır ve şerrin Allah'tan olduğuna imandır. Her şeyin yaratıcısı olan Allah'tır. Bu inancı ölçen sorulardaki iki ifade konu bağlamında değerlendirilmiştir. 'Kesinlikle inanıyorum' ifadesi dışında 'inanıyorum ama bazı şüphelerim var, Kararsızım/fikrim yok, İnanmyyorum, Beni ilgilendirmiyor' şıkları ölçekte mevcuttur. Ayrıca bu soruları cevapsız bırakanlar için bu sorular 'cevapsız' veri olarak değerlendirilmiştir. İman esaslarının başı olan Allah'ın varlığına şüphesiz bir şekilde kesinlikle iman ettiğini söyleyenlerin oranı \%84,5'tir. Bu dünyadan göçtükten sonra ahirete gidip, dünyada yaptıklarının karşılığını göreceğine kesinlikle iman ettiğini söyleyenler ise \%51,4'tür. Görülüyor ki Allah'ın varlığını kabul etmekle birlikte yaşamın bu dünyadan ibaret olduğu alg1sı bazı katılımcılarda mevcuttur. Anket esnasında katılımcılar arasında cennetin ve cehennemin bu dünyada olduğunu ifade edenler olduğu gibi reenkarnasyona benzeyen açıklamalar da yapanlar gözlemlerime göre mevcuttu. Denilebilir ki Kıbrıslı Türkler arasında deizm adı konulmamış bir olgu olarak varlığını korumaktadır.

Tablo 2. Namaz ile ilgili Bulgular 


\begin{tabular}{cc}
\hline & Hiç \\
\hline Cuma namazı & $\% 64,2$ \\
\hline Beş vakit namaz & $\% 60,8$ \\
\hline Teravih namazı & $\% 54,1$ \\
\hline Bayram namazı & $\% 52,7$ \\
\hline
\end{tabular}

Namaz İslam dininde en önemli pratiklerden biridir. Hicri takvime göre farz olan oruç Ramazan ayı geldiğinde, hac ibadeti ise Zilhicce ayında yapılır. Kelime-i şehadetin yeri ve zamanı tayin edilmezken zekât ibadeti ise yılda bir kere yapılır. Hac ve zekât için zengin olmak gerekirken oruç için sağlıklı olmak şarttır. Farz namazı, günde beş defa vakti tayin edilmiş bir şekilde emredilmiştir. Zengin veya sağlıklı olma şartı aranmaksızın kadın erkek her müminin temel ödevidir. Cuma namazı ise erkekler için farz ibadettir. Bir Müslümanın Cuma namazı ile yükümlü olabilmesi için erkek, hür, mukim ve mazeretsiz olması gerekmektedir. Bayram namazı da erkeklere özel olmakla birlikte, Hanifilere göre vacip diğer mezheplere göre de sünnet bir ibadettir. Teravih namazı ise Ramazan ayının olmazsa olmazı nafile bir ibadettir. Ayrıca cemaatle kılınması teşvik edilmiştir. Cemaat olmanın teşvik edilmesi nedeniyle denilebilir ki namaz toplumsal değeri olan bir ibadettir. Katılımcılara namaz ile ilgili sorular sorulmuş, karşılığında ise 'Her zaman, genellikle, ara sıra, nadiren, hiç' cevapları alınmıştır. Ayrıca bu soruları cevapsız bırakanlar için 'cevapsız' veri olarak değerlendirilmiştir. Araştırmanın detaylara saplanmaması için burada 'hiç' şıkkı üzerinden genel bir değerlendirme yapılmıştır. Tablo 2'den de görüleceği gibi katılımcıların yarısından fazlası hiçbir şekilde namaz kılmamaktadır. Bayram namazı ve Cuma namazı erkeklere özel olduğu düşünülürse Cuma namazına katılım oranı daha düşüktür. Yılda iki kere olan bayram namazı ise diğer namaz çeşitlerine göre uygulanma açısından daha iyimser bir tablo çizmektedir. Davie'nin ait olmadan inanma tezi burada kendini hissettirmektedir. Camiye veya cemaate ait olmadan dini pratiklerden yoksun bir inanç kendini göstermektedir.

Tablo 3. Fatiha suresini bilme durumu

\begin{tabular}{|c|c|c|c|c|}
\hline \multirow{10}{*}{$\begin{array}{c}\text { Fatiha Suresini ezbere } \\
\text { biliyor musunuz? }\end{array}$} & & \multicolumn{3}{|c|}{ Cinsiyet } \\
\hline & & Kadın & Erkek & Toplam \\
\hline & \multirow{2}{*}{ Evet } & 53 & 69 & 122 \\
\hline & & $\% 94,6$ & $\% 75,0$ & $\% 82,4$ \\
\hline & \multirow{2}{*}{ Hayır } & 2 & 19 & 21 \\
\hline & & $\% 3,6$ & $\% 20,7$ & $\% 14,2$ \\
\hline & \multirow{2}{*}{ Unuttum } & 1 & 4 & 5 \\
\hline & & $\% 1,8$ & $\% 4,3$ & $\% 3,4$ \\
\hline & \multirow{2}{*}{ Toplam } & 56 & 92 & 148 \\
\hline & & $\% 100,0$ & $\% 100,0$ & $\% 100,0$ \\
\hline
\end{tabular}

$\mathrm{p}: 0,009 \mathrm{p}<0,05$

Fatiha Suresi Kuran-1 Kerim'in ilk sirasında yer alan ve Kuran'ın özeti mahiyetinde bir suredir. Fatiha açılış anlamındadır. Ayrıca bu sure cenazelerde, kabirlerde ve farklı birçok duanın sonunda okunur. Namazın rükünlerinden olan kıraat yani Kuran'dan bir parça okunmasının asgari şartı Fatiha Suresi'ne ek olarak en az bir satırlık bir ayet okunmasıdır. Bu sureyi ezbere bilme durumuna bakıldığı zaman \%82,4 oranında ezbere bilenler ilk sirada yer almaktadır. $\% 14,2$ oranında katılımc ise bu sureyi ezbere bilmediklerini ifade etmektedir. Unuttum diyen 5 kişinin oranı ise \%3,4 oranındadır. Yıldırım, tamamı 25 yaş altı katılımcılardan oluşan 
örnekleminde ise Fatiha Suresi'ni bilenlerin \%81,9 olduğunu tespit etmiştir (Yıldırım, 2016, s. 84).

Fatiha Suresi'ni ezbere bilme durumu ile cinsiyet durumunun ilişkisine bakıldı̆̆ zaman anlamlı (p:0,009) derecede farklılık bulunmuştur. Kadınlar \%94,6 oranında sureyi ezbere bilmektedir. İki kadının ise bu sureyi ezbere bilmedikleri görülmüştür. Bir kişi ise unuttuğunu ifade etmiştir. Erkeklerde ise oranlar kadınlara oranla düşmektedir. Ezbere bilenler \%75 oranında iken, bu sureyi ezbere bilmediğini ifade edenlerin oranı ise \%20,7 oranındadır. Unuttuğunu ifade eden 4 erkek katılımcının oranı ise $\% 4,3$ oranındadır. Örnekleme katılan erkek katılımcilardan her dört kişiden biri Fatiha Suresi'ni ezbere bilmemektedir.

Foto 1. Mermer Fatiha Kitabesi

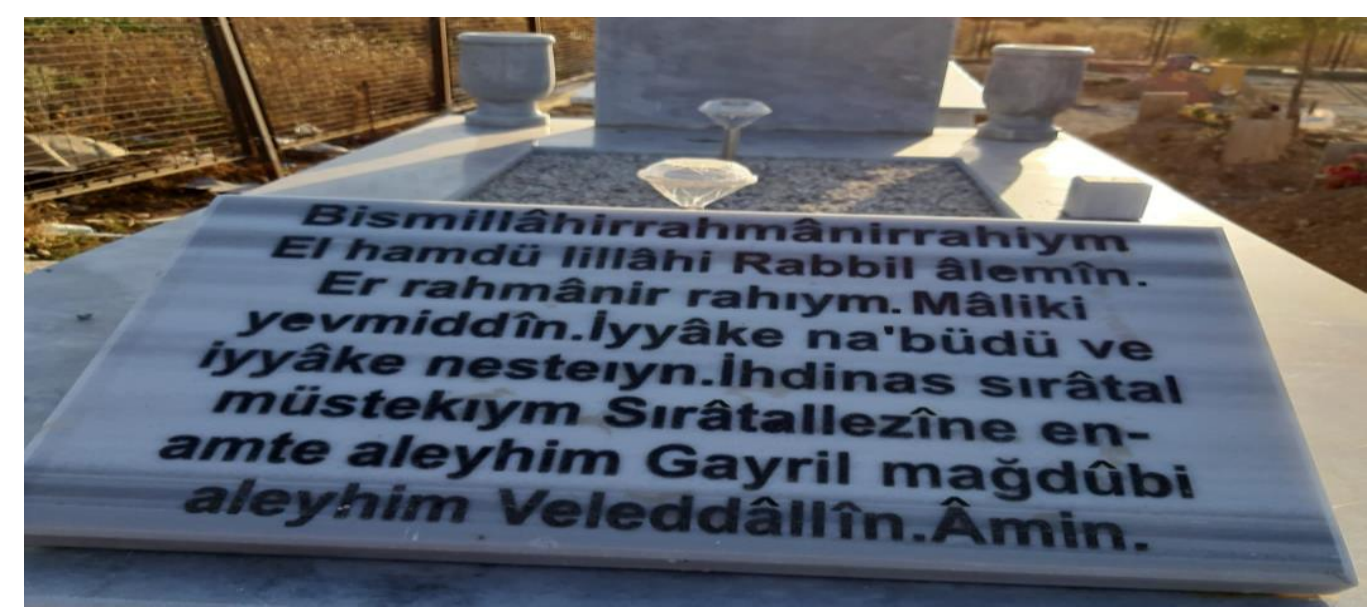

Fotoğraf: İbrahim Sezgin

Foto 1'e bakıldığında Fatiha Suresi'nin Latin harflerle mermer tabletlere yazıldığı görülecektir. Güzelyurt ilçe sınırları içerisinde bulunan Yuvacık Mezarlı̆̆ı'nda yeni yapılan mezarların birçoğunda Fatiha kitabesini görmek olağan hale gelmiştir. Ayrıca bu durum popüler bir uygulama olarak benimsenmiş ve restore edilen eski mezarlara da eklenmeye başlanmıştır. Yapılan araştırmada her dört erkekten biri Fatiha Suresi'ni bilmezken, kadınlar da dâhil edildiğinde bu oran neredeyse her beş kişiden biri olarak karşımıza çıkmaktadır. Toplu yapılan dualarda 'Adı unutulmuş, soyu kesilmiş, bana da bir Fatiha yok mu diyen cümle mümin müminâtın ruhlarına' ifadesi meşhur bir ifadedir. Güzelyurt'ta metfun bulunan kişiler her ne kadar adı unutulmamış, soyu kesilmemiş olsa da günümüzde arkasından Fatiha okuyacak nesiller bırak(a)mamıştır. Bu yüzden olsa gerek Latin harflerle olsa dahi Fatiha Suresi mezarların yanı başında bilmeyenler için durmaktadır. Vekil dinin uygulama sahasında cisimleştiği en bariz örneklerden biri profesyoneller tarafından hazırlanmış Fatiha Suresi'nin mermer tabletleridir. Bu mermer tabletler sureyi bilmeyenler için vekâleten orada durmaktadır. Foto 1'e dikkatle bakıldığı zaman göze çarpan yeni sayılacak bir popüler uygulamadan bahsetmek mümkündür. Güneş enerjisi ile çalışan floresan gece lambaları kabirlerde görülmeye başlanmıştır. Yeni bir uygulama olduğu için kabrin üzerine konma motivasyonunun ne olduğu verilerde mevcut değildir. Tahminen söylemek gerekirse '1şıklar içinde uyu' kelimesinin cisimleştiği bir uygulama denebilir. Ayrıca kabrin iki yanında bulunan mermer vazoların içine de tütsü ya da çiçek konulduğu görülmüştür. 
Tablo 4. Dini törenlere katılma durumu

Toplumsal hayatınızda önemli bir yeri olan (Mevlit, Hatim, Cenaze, yıl dönümü vb.) dini törenlere katılır mısınız?

\begin{tabular}{lcc}
\hline & Frekans & Yüzde \\
\hline Dini bir vazifedir. Bu yüzden katılırım & 86 & $\% 58,1$ \\
\hline Adettir. Herkes katıldığı için katılırım & 47 & $\% 31,8$ \\
\hline Bana ölümü hatırlatır. Bu yüzden katılmak istemem & 3 & $\% 2,0$ \\
\hline $\begin{array}{l}\text { Hayır, katılmam. Günümüz itibariyle bu etkinlikler çă̆ dışı } \\
\text { kalmaktadır }\end{array}$ & 3 & $\% 2,0$ \\
\hline Diğer (Belirtiniz) & 4 & $\% 2,7$ \\
\hline Sevdiklerimi anmak/ ölünün anısını yaşatmak için katılırım & 5 & $\% 3,4$ \\
\hline Toplam & 148 & $\% 100,0$ \\
\hline
\end{tabular}

Bireyler üyesi oldukları toplumların belirli aktivitelerine katılarak toplumun bir parçası olmaktadır. Bu aktivitelere çeşitli anlamlar yüklenmektedir. Mevlit, hatim, cenaze vb. dini törenler toplum üyeleri belirli zamanlarda bir araya getiren aktivitelerin başında gelmektedir (Köse, 2015, s. 10). Toplumsal hayatta önemli yeri olan dini törenlere katılıp katılmama durumu katılımcılara sorulmuştur. 'Dini bir vazifedir. Bu yüzden katılırım' diyen \%58,1 oranındaki katılımcı en kalabalık grubu oluşturmaktadır. Adet olduğunun düşünen ve bu yüzden katılan \%31,8 oranındaki grup ise ikinci sırada yer almaktadır. ‘Bana ölümü hatırlatır. $\mathrm{Bu}$ yüzden katılmak istemem' diyen üç kişi ile 'Hayır katılmam. Günümüz itibariyle bu etkinlikler çağ dışı kalmaktadır' diyen diğer üç kişi \%2'şer orandadır. 'Sevdiklerimi anmak/ ölünün anısını yaşatmak için katılırım' tercihi anket cevaplarında yer almazken diğer tercihinde yer kaplaması nedeniyle ayrıca belirtilme ihtiyacı duyulmuştur. Bu tercihi söyleyenlerin genel olarak kullandıkları söylemler göz önünde bulundurulursa dini törenlerin toplumsal anlamından veya dini anlamından öte sadece kişiye saygı amaçlı tören olarak ifade ettikleri anlaşılmaktadır. Yani dinden ve adetlerden soyutlanmış bir ifade olduğu söylenebilir. $\mathrm{Bu}$ cevabı verenlerin oranı da \%3,4 oranındadır. Diğer tercihindeki iki kişi sebep belirtmemiştir. Öteki iki kişi ise şıklarda yer alanların aksine genel olarak dini törenler katılmadıklarını belirtmiştir. Genel olarak değerlendirildiği zaman dini törenler (özellikle cenaze merasimleri) Kıbrıs Türkü için toplumsal bir işleve sahiptir. Davie'nin de dikkat çektiği gibi cenaze törenleri seküler toplumlarda bile en önemli etkinlikler olarak karşımıza çıkmaktadır.

Tablo 5. Halk inanışlarını ve pratiklerini uygulama durumu

Aşağıdakilerden hangilerini yaparsınız?

\begin{tabular}{lcc}
\hline & Sayi $^{*}$ & Yüzde \\
\hline Mezarlı̆̆a giderken okunmuş su götürmek & 86 & $\% 58,1$ \\
\hline Buhur, tütsü yakmak & 71 & $\% 48,0$ \\
\hline Mevlit okumak (veya okutmak) & 69 & $\% 46,6$ \\
\hline Türbe ziyaret etmek & 57 & $\% 38,5$ \\
\hline Nazar boncuğu takmak & 41 & $\% 27,7$ \\
\hline Türbelere mum dikmek & 19 & $\% 12,8$ \\
\hline Muska yazdırmak / Muska takmak & 18 & $\% 12,2$ \\
\hline Kurşun döktürmek & 15 & $\% 10,1$ \\
\hline Hatim indirtmek için birini görevlendirmek & 11 & $\% 7,4$ \\
\hline
\end{tabular}




\begin{tabular}{lcc} 
Hatim indirmek & 8 & $\% 5,4$ \\
\hline Dini motifli yüzük, kolye vb. takmak & 8 & $\% 5,4$ \\
\hline Ağaçlara çaput bağlamak & 1 & $\% 0,7$ \\
\hline $\begin{array}{l}\text { Hiçbiri } \\
\text { *Çoklu yanıt verildiğinden } \\
\begin{array}{l}\text { büyüktür. } \\
\hline\end{array}\end{array}$ & 20 & $\% 13,5$ \\
\hline
\end{tabular}

Halk arasında rağbet gören birtakım uygulamalardan hangilerini yaptıkları katılımcılara sorulmuştur. En yüksek oranda tercih edilen \%58,1 ile mezarlığa giderken okunmuş su götürme adeti olduğu saptanmıştır. Kıbrıs'ta yaygın olan bu uygulama genellikle Kur'an okumayı bilmeyen kişilerin başvurduğu bir adettir. Mezarlığa gitmeden önce su ile doldurdukları şişeleri Kur'an okumasını bilen birilerine götürerek Yasin, Fatiha, İhlas vb. sureleri okutulur. Daha sonrasında ise ziyaret edilen kabrin üzerine dökülür. İkinci en çok yapılan uygulama ise nazardan koruduğuna inanılan tütsü veya buhur yakma âdetidir. Buhur zeytin yapraklarının yakılmasıyla ortaya çıkan kokulu dumanı etrafa dağıtmak suretiyle nazardan koruduğuna inanılan uygulamadır. Mevlit okutma ise Süleyman Çelebi'nin Hz. Muhammed (sav) için yazmış olduğu nâatın kutsal gün ve gecelerde, düğünlerde ve özellikle cenazelerde okunmasıdır. Mevlit okutmak cenaze törenlerinde ve onu takip eden perşembesi, haftası, kırkı ve yıl dönümlerinde en çok yapılan uygulamadır. Mevlit okutmak \%46,6 ile en çok yapılan uygulamaların başında gelmektedir. Ermiş'in Mesarya Ovası'nda yaptığı alan çalışmasında ise mevlit okutanların oranı \%58,9'dur (Ermiş, 2016, s. 228).

Türbe ziyaret etmek ise \%38,5 sıklığında yapılmaktadır. Anket yaparken gözlemlediğim kadarıla türbe ziyareti Hala Sultan, Kırklar vb. din büyüklerinin kabirleri olarak algılandığ gibi yakınlarının mezar ziyareti olarak da algılanmaktadır. Nazardan korunmanın bir diğer yolu olduğuna inanılan nazar boncuğu takma \%27,7; türbelere mum dikme \%12,8; Muska takma veya yazdırma \%12,2; Kurşun döktürme \%10,1 oranındadır. Hatim indirmek için birini görevlendirenlerin oranı $\% 7,4$ iken şahsen hatim indirenler ise $\% 5,4$ oranındadır. Dini motifli yüzük, kolye vb. aksesuarları takınanların oranı da \%5,4'tür. Ağaçlara çaput bağladığını söyleyen bir kişi de \%0,7 oranındadır. Hiçbirini yapmadığını söyleyenlerin oranı ise \%13,5'tir.

Foto 2. Yeni gömülen birine ait mezarın üzerindeki su ve yanan tütsü çubukları

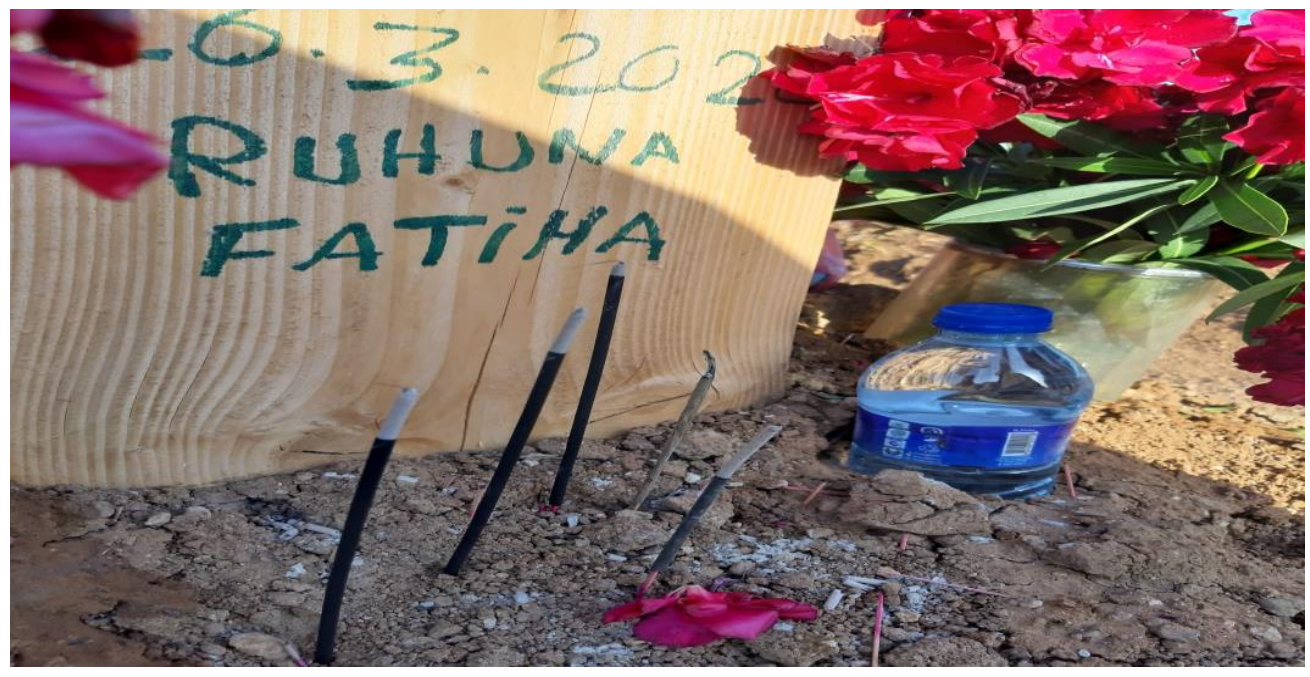

Fotoğraf: İbrahim Sezgin 
Mezarlığa giderken okunmuş su götürmek farklı bir açıdan bakıldığında Kuran okumayı bilmeyen kişiler için vicdani bir rahatlama olduğu söylenebilir. Mezara gömülen kişinin arkasından Yasin okutmak, dini ve örfi bir uygulama olduğu için, okunmamış olması akrabalarının vicdanını rahatsız etmektedir. Bu yüzden okunmuş su uygulaması Kıbrıs özelinde, Davie'nin de söylediği gibi 'vekâleten' icra edilen dini bir pratik haline dönüşmüştür (Davie, 2005, s. 91-92). Okunmuş sudan kasıt Kur'an okumayı bilen profesyonel biri (genelde din görevlisi) tarafından mezarlıkta okunması gereken sureler okunduktan sonra içi su dolu şişeye üflenmesidir. Bu su daha sonrasında cenaze sahipleri tarafından mezarlığın üzerine dökülmektedir. Foto 2'ye bakıldığında yeni yanan tütsü çubukları göze çarpmaktadır. Ayrıca içi su dolu bir şişe de hazırda bekletilmektedir.

Sosyal hayatta dinle ilişkinin neredeyse cenaze törenlerine indirgenen bir toplumda mevlit okutmak, Kıbrıs özelinde çok önemli bir adettir. Doğum, sünnet, düğün ve cenaze törenlerinde okunan mevlit, toplum için 'anchoring'-çıpa- (Köse, 2015, s. 10) görevi görmektedir. 'Anchoring' kavramı, geminin savrulmasını engelleyen demirleme veya karaya tutunmasını sağlayan çıpalama olayına benzetilmektedir. Dinle ilişkisi en aza inmiş toplumlarda bile doğum, sünnet, düğün ve cenaze merasimleri nedeniyle mevlid-i şerif, Yasin, İhlas, Fatiha vb. sureler okunmakta, dualar edilmektedir.

Kilise ayinlerinde ayini yöneten kişinin buhurdanlık ile etrafa koku yayma uygulaması, Kıbrıslı Türklerde de nazardan korunmanın ve bereketin sembolü olarak algılanmaktadır. Yine türbelere mum dikme âdetinin de Hristiyan temelli bir uygulama olduğunu söyleyebiliriz. Hatim indirmek için birini görevlendirme yapılan pratikler açısından alt sıralarda yer alırken kendisi hatim indirenler ise daha azdır. Yine aynı şekilde dini motifli kolye ve yüzük takmak da az rastlanan bir uygulamadır. Bir kişi ise ağaçlara çaput bağladığını söylemektedir. Anlaşılacağı üzere Kıbrıslı Türklerde ağaçlara çaput bağlama uygulaması çok rastlanan bir uygulama değildir.

Tablo 6. Katılımcıların Din Görevlisinin Günah İşlemesi Hakkındaki Düşünceleri Cami görevlisini herhangi bir barda veya night clubta görseniz ne düşünürdünüz?

\begin{tabular}{lcc}
\hline & Frekans & Yüzde \\
\hline Din görevlisi ise bu tür durumlardan uzak durmalıdır & 54 & $\% 36,5$ \\
\hline Din görevlisi olduğu için yakıştırmazdım & 35 & $\% 23,6$ \\
\hline Din görevlisi ama o da insan. Hata yapabilir & 12 & $\% 8,1$ \\
\hline Din görevlisi olması eğlenemeyeceği anlamına gelmez & 34 & $\% 23,0$ \\
\hline Bu konuda fikrim yok & 12 & $\% 8,1$ \\
\hline Toplam & 147 & $\% 99,3$ \\
\hline Kayıp veri & 1 & $\% 00,7$ \\
\hline Toplam & 148 & $\% 100,0$ \\
\hline
\end{tabular}

Fâsık alenen günah işleyen kişi demektir. Dini açıdan fâsık bir kimse imam olma hüviyetine sahip değildir. Cemaat imamın fâsık olduğunu bilirse arkasında namaz kılmayabilir. Katılımcılara 'Cami görevlisini herhangi bir içki içilen barda ya da zina yapılan gece kulüplerinde (night club) görseniz ne düşünürdünüz?' diye sorulmuştur. Bu soruyu da bir kişi yanıtlamamıştır. Verilen cevaplar arasında en yüksek oran \%36,5 ile ‘Din görevlisi ise bu tür durumlardan uzak durmalıdır' yanıtıdır. Din görevlisine bu tür durumları yakıştıramayanlar ise ikinci sırada yer alarak \%23,6 oranındadır. Din görevlisinin açıkça günah işlememesi gerektiğini düşünenlerin toplam oranı \%60,1'e tekabül etmektedir. Daha 1lıman bir bakış 
açısıyla din görevlisinin de insan olduğu ve hata yapabileceği görüşüne sahip olanlar \%8,1 oranındadır. Din görevlisinin açıkça günah işlemesine aldırış etmeyenlerin oranı ise \%23'tür. Toplumun belirgin bir kısmı din görevlisinin fâsık olmasını kabul etmemektedir. Ancak azımsanmayacak oranda bu duruma aldırış etmeyenler de mevcuttur. Piskopos David Jenkins'in başına geldiği gibi KKTC'de de alenen günah işleyen imamlar medya önüne atılıp ayıplanmaktadır. Ayrıca alınan bu cevapların içkinin ve gece kulüplerinin çokça ve ulu orta her yerde olduğu bir yörede alındığı göz önünde bulundurulmalıdır.

Tablo 7. Dindarlı̆̆ıı göstergesi sayılan davranışlar

Aşağıda sayılan davranış kalıplarından hangileri size göre dindarlığın göstergeleri arasinda yer alır?

\begin{tabular}{lcc}
\hline & Frekans & Yüzde \\
\hline Kalbi temiz olmak & 108 & $\% 74,5$ \\
\hline Merhametli olmak & 102 & $\% 70,3$ \\
\hline Yardım faaliyetlerine katılmak & 71 & $\% 49,0$ \\
\hline Ahlaki ilkelere bağlı olmak & 63 & $\% 43,4$ \\
\hline Dini kitaplar okumak & 56 & $\% 38,6$ \\
\hline İbadethaneler için bağışta bulunmak & 53 & $\% 36,6$ \\
\hline Dini pratiklere ve inançlara değer vermek & 53 & $\% 36,6$ \\
\hline Yetimin başını okşamak & 52 & $\% 35,9$ \\
\hline${ }^{*}$ Çoklu yanıt verildiğinden dolayı tablo sayısı örneklemin hacminden büyüktür.
\end{tabular}

İbadet etmenin dışında kişiyi dinle alakalı, dine meyilli olduğunu gösteren birtakım pratikler bulunmaktadır. Dinin sadece mabetlere yaşandığını düşünmek olanaksızdır. Özellikle de İslam gibi hayatın her alanında kuralları olan bir dinden bahsediliyorsa bu durum olanaksızdır. Katılımcılara dindar olan bir kişinin hangi davranışları sergileyeceği sorulmuş ve üç kişiden yanıt alınamamıştır. Bu kişiler kayıp veri olarak işlenmiştir. Ayrıca seçenekler arasında birden çok cevap verebilecekleri söylenmiştir.

Kalp temizliği Kıbrıslı Türklerde en önemli dindarlık göstergelerinden biridir. \%74,5 ile en çok tercih edilen yanıt kalp temizliğidir. Merhametli olmak da \%70,3 gibi yüksek bir oranda tercih edilmiştir. Örneklemin yarıya yakını \%49 oranında yardım faaliyetlerine katılmayı da dindarlığın göstergesi olarak saymaktadır. Ahlaki ilkelere bağlı olmak ise \%43,4 oranındadır. Sıralama da ilk dört gösterge soyut ve manevi duygularla alakalıdır. Geri kalan dört gösterge bireyin aktif olarak müdahalesinin bulunduğu göstergelerdir. Beşinci sırada yer alan dini kitaplar okumak tercihi \%38,6 oranındadır. İbadethaneler için bağışta bulunmak ile dini pratiklere ve inançlara değer vermek \%36,6 oranındadır. Yetimin başını okşamak ifadesi ise $\% 35,9$ oranindadir.

Verilen cevaplara baktığımız zaman ilk dört sırada bireyin vicdanı ile olan seçeneklerin yer aldığı görülmektedir. Kalp temizliği yaygın kullanılan bir ifade olsa da hangi kalbin ne kadar temiz olduğu ya da niçin temiz olduğu kişilere göre değişebilmektedir. Yine merhametli olmak ifadesi de kalp temizliği ifadesindeki gibi kişinin mizacıyla alakalı bir durumdur. Merhametli olma ve kalbi temiz olma durumları fiziki olarak ölçülebilecek bir durum değildir. Yardım faaliyetlerine katılmak mali bir yardım olabileceği gibi manevi bir destek de olabilir. Ayrıca kimin ne oranda yardım yapacağı kişinin kendi vicdanını bağlayan bir durumdur. Ahlaki ilkelere bağlı olmak ise biraz daha sınırları belli bir ifadedir. İnsan doğduğu toplumun özellikleriyle anlam bulur (Mardin, 1993, s. 24). Anlam, toplumda var olan etik kuralları, ahlaki 
ilkeler, gelenek ve görenek vb. manevi aktarımlardır. Bunun yanında dinin de ortaya koymuş olduğu ahlak kuralları vardır. Din ile kurulan dünyanın idamesi ve düzeni, yine din ile olacaktır (Ekinci, 2018, s. 325). Tablodan ve önceki verilerden de anlaşılacağı gibi Kıbrıslı Türkler dini yeniden anlamlandırmıştır. Ancak bu yeni anlam dünyasında bireysellik ön plana çıkmaktadır.

\section{SONUÇ ve DEĞERLENDİRME}

Kıbrıs küçük bir memleket olmasına rağmen tarihin her döneminde egemen güçleri kendine çekmeyi başarmış ender yerlerden biridir. Konum itibariyle Kuzey Afrika, Levant ve Anadolu'nun kesiştiği bir kavşakta yer alması bunun başlıca nedenidir. Adaya gelen her devlet burayı vatan bilmiş, kendinden bir şeyler bırakmıştır. Bu yüzden tarihi, kültürel ve sosyolojik açıdan zengin bir adadır. Adanın çokuluslu yapısının temeli de bu zenginliğe dayanmaktadır.

İslam'ın ilk yıllarından beri Müslümanlara, Osmanlı'nın fethinden beri de Müslüman Türklere ev sahipliği yapmış olan ada, emperyal güçlerin birtakım çekişmeleri nedeniyle el değiştirmiş ve İngilizlere kiralanmıştır. Zamanla İngiliz sömürgesine dönüşünce adada Müslümanlar için zor günler başlamıştır. Siyasi otorite kaybı, dini eğitimin yokluğu, Müslüman ahaliden uzak oluşu, İngiliz sömürgeciliği, çokuluslu yapısı vb. daha sayamadığımız birçok faktörün etkisiyle sosyo-kültürel dinamikler değişmeye başlamıştır. Bunlara ek olarak bu çalışmada vurgulandığı gibi dünyadaki modern-seküler hareketlilik adalı Müslümanları da derinden etkilemiştir. Bu çalışma kapsamında değerlendirilmeyen ama adadaki sosyo-dini yapıyı etkileyen hususlar elbette vardır. Makalenin kapasitesi doğrultusunda önemli gördüğümüz bazı hususlar özellikle belirtilmiştir.

Allah'ın varlığına kesinlikle inanan \%84,5 iken ahiretin varlığına inanan \%51,4 oranına gerilemektedir. Tablo 2'de ise örneklemin yarısından fazlası hiçbir surette namaz kılmadığı tespit edilmiştir. Bu iki örnek bile pratikten ayrılan bir dindarlığ gözler önüne sermektedir. Allah'ı bilme durumu başlıca iman göstergesi iken dini pratikler göz ardı edilmektedir. Ayrıca Fatiha suresinin mermer tabletlere aktarılma durumu da verilere göre anlamlllı arz etmektedir. Tablo 3'te örneklemin \%82,4'ü Fatiha Suresini ezbere bildiğini beyan etmiştir. Bilmeyenlerde ise erkeklerin çokluğu göze çarpmaktadır. Bu konuyla alakalı olarak okunmuş su uygulamasına müracat edenlerin oranı da \%58,1 ile en çok yapılan uygulamadır. Her ne kadar adet olarak toplumda anlam kazanmış olsa da pratikte Kur'an okumayı bilmeyen bir toplum için okunmuş su uygulaması 'anchoring'-çıpa görevi görmektedir. Kıbrıslı Türkler açısından dinin sosyal hayatta en görünür olduğu yerlerden biri de cenaze merasimleridir. Davie'nin dediği gibi seküler toplumlarda bile cenaze merasimleri hala önem arz etmektedir.

Özetle vekil dinin mahiyeti, dini pratiklerin halk adına profesyoneller tarafından icra edilmesidir. Okunmuş su, Fatiha suresinin mermer tablete aktarılması, kalbi temiz olmak vb. örneklerde görüleceği gibi alışılmışın dışında farklı dini pratikler çalışmada kendini göstermektedir. Bu çalışmada profesyonel ellerde dönüşüme uğrayan, özelleşen ve de bireyselleşen bazı dini pratiklerin yansıması analiz edilmiştir. Burada bahsettiğimiz profesyonellik Strauss'un da değimiyle brikolaj yapan insanınki kadardır. Ortaya çıkan durum ise mevcut şartları kendine uyarlayan, yok olmayan ancak dönüşen bir dindarlıktır. 


\section{KAYNAKÇA}

Bayet, A. (2016). Dine karşı düşüncenin tarihi. (C. Süreyya, Çev.) İstanbul: İnkılap Kitapevi Yayınları.

Berger, P. L. (2009). Günümüz din sosyolojisi üzerine düşünceler (İ. Çapçığlu, Çev.). B. Solmaz ve İ. Çapçığlu (Ed.). Din Sosyolojisi Klasik ve Çağdaş Yaklaşımlar (s. 245-262). içinde (2 b.). Konya: Çizgi Kitapevi.

Birekul, M. (2009). Avrupa Birliği'ne üyeliğin Türk toplumunun dînî hayatına yansımaları: gelecekle ilgili beklentiler. Yayınlanmamış Doktora Tezi, Selçuk Üniversitesi, Konya.

Davie, G. (2006). Avrupa: Kuralı doğrulayan istisna mı? (İ. Toker, Çev.) Ankara Üniversitesi İlahiyat Fakültesi Dergisi, 47(1), 219-238.

Davie, G. (2012). Belief and unbelief: two sides of a coin. Approaching Religion, 2(1), 3-7.

Davie, G. (2008). Din ve toplum: Avrupa deneyimi bir istisna mı? (T. Küçükcan, Çev.). A. Köse ve T. Küçükcan (Ed.). Avrupa Birliği ülkelerinde din devlet ilişkisi (s. 31-42) içinde. İstanbul: İSAM Türkiye Diyanet Vakfı Yayınları.

Davie, G. (2005). Modern Avrupa'da din. (A. Demirci, Çev.) İstanbul: Küre Yayınları.

Davie, G. (2010). Vicarious religion: A response. Journal of Contemporary Religion, 25(2), 261-266.

Dayığlu, A. (2014). Kuzey Kıbrıs'ın "Ötekileri" Rumlar, Marunîler, Romanlar, Aleviler, Kürtler. Lefkoşa: Kıbrıslı Türk İnsan Hakları Yayınları.

Dereli, M. D. (2016). Bir din sosyoloğu olarak Peter L. Berger'in entelektüel portresi. Bilimname, $31(2), 227-244$.

Ekinci, İ. (2018). Sekülerleşme ve din. Bitlis Eren Üniversitesi Sosyal Bilimler Enstitüsü Dergisi, $7(1), 320-337$.

Ermiş, H. (2016). Kuzey Kıbrıs Türk toplumunda sosyal ve dini hayat (Mesarya örneği). Yayınlanmamış Doktora Tezi, Ankara Üniversitesi, Ankara.

Günay, Ü. (2017). Din sosyolojisi. (14 b.). İstanbul: İnsan Yayınları.

Hervieu-Leger, D. (2009). Sekülerleşme, gelenek ve dindarlığın yeni şekilleri: bazı teorik öneriler. (H. Aydınalp, Çev.). B. Solmaz ve İ. Çapçığlu (Ed.). Din sosyolojisi klasik ve çă̆daş yaklaşımlar (s. 109-124) içinde (2 b.). Konya: Çizgi Kitapevi.

Köse, A. (2001). Modernleşme-sekülerleşme ilişkisi üzerine yeni paradigmalar. Liberal Düşünce Dergisi , 24(Güz), 150-165.

Köse, A. (2015). XXI. yüzyıl Türkiye'sinde gelenekle modernite arasında din algıları ve dindarlık formları: sosyolojik bir bakış. Marmara Üniversitesi İlahiyat Fakültesi Dergisi, 49(Aralık), 5-27.

Levi-Strauss, C. (1996). Yaban düşünce. (T. Yücel, Çev.) (2 b.). İstanbul: Yapı Kredi Yayınları.

Mardin, Ş. (1993). Din ve ideoloji. (6 b.). İstanbul: İletişim Yayınları.

Özay, M. (2020). Sekülerleşme ve din: Batı'da sekülerleşme teorileri ve tartışmaları. (2 b.). İstanbul: İbn Haldun Üniversitesi Yayınları. 
Sezgin, İ. (2019). Kıbrıslı Türklerin dini yaşayışları üzerine karşılaştırmalı bir çalışma (Güzelyurt örneği). Yayınlanmamış yüksek lisans tezi, Necmettin Erbakan Üniversitesi, Konya.

Solmaz, B. (2011). Dine sosyolojik bakış açılarındaki gelişmeler. Selçuk Üniversitesi İlahiyat Fakültesi Dergisi , 31, 29-54.

Şengil, V. (2010). Dinler tarihi açısından Kuzey Kıbrıs Türk Cumhuriyeti'ndeki Marunîler. Yayınlanmamış yüksek lisans tezi, Selçuk Üniversitesi, Konya.

Turner, B. (2012). Post-seküler toplumda din. (Ö. Güngör, Çev.) Din Bilimleri Akademik Araştırma Dergisi, 12(3), 199-224.

Turner, B. (2017). Sivil din. (Y. Aktay, Çev.). Y. Aktay ve M. E. Köktaş (Ed.). Din sosyolojisi (s. 277-291) içinde. (4 b.). İstanbul: Vadi Yayınları.

Yıldırım, E. (2016). Mă̆usa'da dini hayat. Yayınlanmamış yüksek lisans tezi, Marmara Üniversitesi, İstanbul. 